\title{
Analysis The Level of Compliance of Hospital Human Resources in Writing The Status of Inpatient Medical Record Dr Sayidiman Hospital and The Influences Factors
}

\author{
Ratnawati \\ Magister of Health Study Program \\ of Institut Ilmu Kesehatan \\ STRADA Indonesia \\ Email: \\ ratnawati@gmail.com
}

Received : October 12, 2019

Accepted : February 13, 2020

Published : May 12, 2020

\section{ABSTRACT}

The quality of medical records in hospitals also determines the quality of service, completeness of writing Medical Records documents correctly and correctly is very important. The purpose of this study was to analyze the level of compliance of hospital human resources in writing the status of the inpatient Medical Record Dr. Sayidiman Magetan Regional Hospital and the factors that influence it. The design of this study was an observational quantitative study with a cross section approach with the focus of the research directed to be analyzing the level of compliance of hospital human resources in writing the status of the inpatient Medical Record Dr Sayidiman Magetan Regional Hospital and the factors that influenced it with a sample of 192 respondents taken with the Simple Random Sampling technique. The findings found that most of the respondents have high motivation that is 144 respondents $(75 \%)$. Most of the respondents care to write in the medical record that is 160 respondents (83.3\%). Most of the respondents have a high appreciation of 136 respondents (70.8\%). Most of the respondents did not comply doing medical record writing of 107 respondents (55.7\%). Based on the Linear Regression analysis the motivation variable on compliance $\mathrm{p}$ value $0.015<0.05$, the variable concern for compliance $p$-value $0.025<0.05$ then $\mathrm{H} 0$ is rejected so there is the influence of motivation and concern for compliance with medical record writing by health professionals in Regional General Hospital Dr. Sayidiman Magetan. Linear regression variable rewards for compliance shows that the p-value of $0.665>0.05$ then $\mathrm{H} 0$ is accepted so it is concluded that there is no effect of rewards on compliance with writing medical records by health professionals at the Dr Sayidiman Magetan Regional General Hospital. It is expected that respondents can comply to fill out medical records so that the delivery of care to passion can be well integrated.

Keywords: Compliance, Care, Motivation, Awards

\section{(2) (1) ( ()}

This is an open-acces article distributed under the terms of the Creative Commons Attribution-ShareAlike 4.0 International License. 


\section{INTRODUCTION}

Based on Permenkes No. 269 / MENKES / Per / III / 2008 concerning Medical Records, every health service including Hospitals is required to hold medical records. Medical Record service system is a system that organizes forms, records, and reports that are coordinated in such a way as to provide the documents needed by hospital management and implemented for patients who are seen as whole human beings (Permenkes, 2008).

The quality of medical records in hospitals also determines the quality of service, completeness of writing Medical Records documents correctly and correctly is very important. This is because the medical record is one of the standards that must be met by hospitals to get the accreditation title.

In a complete medical record can be obtained information that can be used for various needs. These needs include as evidence in legal cases, research and education materials and can be used as a tool for analysis and evaluation of the quality of services provided by hospitals. In the context of improving the quality of services in the Regional General Hospital Dr. Sayidiman Magetan and the importance of medical record documents, it is necessary to control the filling of medical record documents. Basically the medical record is an important part of health services in hospitals.

Simanjuntak, Martha (2018), With the title Review of physician compliance in filling medical records at the Indonesian Labor Imelda General Hospital (RSUIPI) Medan in 2018, this type of research is a descriptive study that aims to describe the situation at the research site using the observation method. Research variables are HR (General Physician, Neurologist, Pediatrician and Internal Medicine) and CPPT medical record data (Doctor's Name, Anamnese, Medical Diagnosis, Doctor's Signature, Patient Therapy, Hours of Action, Date of Treatment).

Based on the Minister of Health Regulation (Regulation of the Minister of Health) Republic of Indonesia number 4 of 2018 regarding Hospital obligations and patient obligations, in Chapter I in the general provisions of article 1 paragraph 1 and 2 it is stated that: Hospital is a health service institution that organizes individual health services in a complete manner. provide inpatient, outpatient and emergency services. Patients are all people who consult their health problems to obtain the necessary health services, both directly and indirectly at the Hospital (Permenkes, 2018).

Facing the ASEAN Economic Community (AEC) is in sight, as far as our readiness to face the challenges of the free market in the world of medicine and competition in the world of work, for that we need to improve the quality of health services through Hospital Accreditation. According to the SNARS accreditation assessment standard edition 1 in Chapter 8 of the Immigration and Medical Records Management Standard (NIRM), the Hospital carries out management related to Patient care in accordance with laws and regulations. In the NIRM 8.EP 1 assessment element it is stated that there is a work unit that manages medical records that has a Regulation and a program to manage Medical Records in accordance with applicable regulations.

According to the Law of the Republic of Indonesia Number 44 Year 2009 concerning Hospitals article 29 section states that each hospital has the obligation to hold medical records. Whereas according to Permenkes (Minister of Health Regulation) Number 55 Year 2013 concerning the Implementation of Medical Record Work in Chapter I article 1 paragraph 2 it is mentioned that what is meant by Medical Record is a file containing records and documents about patient identity, examination, treatment, actions and other services to patients in health care facilities (Permenkes 2013).

Based on survey data, there was a lack of achievement in writing medical records documents that were fully loaded at the Regional General Hospital, Dr. Sayidiman (RSDS) Magetan in 2018, which should have achieved the target of $100 \%$, in fact only reached $70.8 \%$ of the 2018 Medical Record Review Report. Even though the Regional General Hospital Dr. Sayidiman Magetan has been accredited since November 30, 2016, Plenary accreditation according to the Accreditation version 2012, while currently in preparation for the upcoming November 1, 2019 SNARS accreditation assessment. The medical record is called complete if the medical record already contains all information about the patient including the medical resume, nursing and all the results of supporting examinations and has been initialed / signed by the doctor in charge of service (DPJP) the maximum time of entry / return to the medical record for the patient hospitalization is $2 \times 24$ hours according to the standard of completeness of $100 \%$ medical record filling (MOH RI, 2007).

The quality standard set in the completeness of filling medical records within 24 hours after completion of service is $100 \%$. But in practice, filling out the complete medical record is still far from the set standards. Based on the results of observations made, the discrepancy is caused by the 
incompleteness of the contents of the Medical Record sheet, specifically the signature of the patient responsible doctor on the medical resume (Aufa et al, 2018)

The results of the evaluation of the Medical Record Review of Dr. Sayidiman Magetan Hospital in 2018 found that the figures were not much different each month, if there was an increase, the changes were only in different inpatient rooms, but the average results were almost the same. , February and October 2018 with 78\% results while the lowest results in May and June 2018 at 64\% of the 100\% standard set by the RI Ministry of Health.

With the background that we have explained above, the authors are interested in conducting research on "Analysis of hospital HR compliance levels in writing the status of inpatient Medical Record Dr. Sayidiman Magetan Regional Hospital and the factors that influence it.

\section{METHODS}

In this study, researchers used a quantitative analytic design with a cross sectional approach which is a study to study the dynamics of the correlation between risk factors and effects, by way of approach, observation or data collection at a time (point time approach), that is, each subject the study was only observed once and measurements were made on the character status or subject variables at the time of examination. This does not mean that all research subjects were observed at the same time (Soekidjo, 2002). This study will analyze the level of compliance of hospital human resources in writing the status of the inpatient Medical Record Dr. Sayidiman Magetan Regional Hospital and the factors that influence it.

The number of samples of this study were 192 respondents with sampling techniques using simple random sampling.

\section{RESULTS AND DISCUSSION \\ Motivation in Writing Medical Records By DPJP, Paramedics, Nutritionists, Pharmacists in the Regional General Hospital Dr. Sayidiman Magetan}

The results showed that most of the respondents had high motivation, 144 respondents (75\%). Whereas 48 respondents (25\%) had low motivation.

Motivation is something that is owned by the individual to provide stimulus and strength in activating and moving behavior towards the goals to be achieved. Motivation refers to positive encouragement from within or outside the individual self that drives the desire of individuals to achieve goals Motivation theory is a process that describes each individual actively in carrying out an action in accordance with organizational expectations. The thing that is able to move the motivation is the expectation obtained by the individual. (Revitasari, 2016).

Increasing one's motivation for a type of behavior can be done by giving gifts in the form of objects or materials. It can be explained that there are a number of other aspects that contribute to influencing physician compliance to fill medical records. These factors include doctor's educational background, doctor's tenure, doctor's skills, motivation level, work facilities, working time, written guidelines, and adherence to the guidelines and psychological factors

Motivation can affect job performance and performance can affect motivation too. Individual intensity, direction and persistence of efforts to achieve goals become motivation in a non-monetary perspective. It is important to have motivation to achieve individual and organizational goals. This gives employees the strength to finish their work on time and be satisfied with what they are doing (Sultan and Abidin, 2013).

This is in line with the statement of the work team from WHO in Dewi (2014) which states that a person behaves certain because there are four main reasons, namely thoughts and feelings in the form of knowledge, motivation, perception, attitude, belief and values of an object, important people as a reference, resources and normal behavior that is habits and values.

Based on Salami's (2013) research, motivation has a significant relationship with the behavior of specialist doctors in charging RM and is in line with the research of Setyawati and Muchlas (2014) who found that motivation is directly related to the behavior of specialist doctors. The study concluded that the higher the motivation of a specialist doctor would contribute to the tendency of the behavior of specialist doctors, the better.

Based on the results of cross tabulation between sexes with motivation, it proves that health workers with female sex have more motivation in writing medical records. In this case women are more 
diligent to write compared to men. However, there are some respondents who are female who have low motivation, which is because the activity that is being done is very dense, sometimes filling in the medical records is incomplete.

Based on the results of cross tabulation between age and motivation, respondents aged 25-45 years have higher motivation in filling out medical records, which is because at that age they still have a high enthusiasm to always do something and a high desire to do something perfectly. However, there are some respondents aged 46-65 years who have less motivation where it is caused by respondents at that age who prioritize actions to patients that must be done and also more to delegate with other officers so that there is rarely time to write medical records in full, this is due to the double duty of a paramedic who is the head of the room, a member of the committee or a member of the Accreditation Working Group, so many do other administrative tasks as well as monitoring and evaluating staff under them

Based on the cross tabulation on marital status, respondents who were married were more likely to have high motivation to complete a complete medical record. Then in the educational history, diploma graduates have a high motivation in writing a complete medical record in which it is caused because paramedics diplomas are more painstaking in conducting direct activities such as actions to patients. Whereas in the work history, it is found that officers who have PNS status have high motivation to complete medical records, which is because the officers with PNS status have great responsibility for writing medical records and often the PNS recommends their work to be carried out by the junior where is the intern nurse where it rains to teach the junior.

From 18 questions Motivation found questions number 10 and 16 have low answers, namely respondents have hopes of writing a digital medical record and dislike writing a medical record. Then it can be evaluated digitally writing needs to be considered, the use of electronic media needs to be prepared again.

Motivation is a driving force that results in a member of an organization willing and willing to give up abilities in the form of expertise or skills, energy and time to carry out various activities that are their responsibilities and fulfill their obligations in order to achieve the goals and various predetermined organizational goals. Based on the results of this study it was found that the majority of respondents had high motivation to complete complete medical record data because it was because the health worker assumed he felt responsible for filling out the complete medical record. However, there are some respondents who have low motivation where it is caused because health workers consider medical records only for formalities and less important to fill in all patient activities on the sheet, health workers consider that more important is to ensure that patients can get well soon and recover quickly because getting the right health services.

\section{Concern for Writing Medical Records By DPJP, Paramedics, Nutritionists, Pharmacists at the Regional General Hospital Dr. Sayidiman Magetan}

The results showed that the majority of respondents cared about writing on medical records, namely 160 respondents $(83.3 \%)$. Whereas 32 respondents $(16.7 \%)$ did not care to write to the medical record.

$\mathrm{RM}$ is important because it plays a role in the implementation of good hospital management activities, especially in improving the quality of hospital services. RM acts as a communication medium between doctors and other health workers in providing services to patients. RM records or contains data about the care and treatment that has been given, how the dosage and its effects so that it can be used as material for planning the next stage of treatment and treatment (Waruna, 2013).

Specifically, RM provides special data that is useful for research and education purposes. Rare cases of disease or rudimentary treatment can be recorded so that they can be followed up and raised as topics of scientific discussion to find a way out. Other uses of the RM are taken into consideration in making decisions for the development of a rational hospital (planning data). Even RM has legal aspects that need to be realized by all parties in the hospital including leaders, doctors, nurses, registrants, and patients (Waruna, 2013). This was confirmed by Hatta (2013) that a qualified RM can help health practitioners and other parties as concrete evidence in solving various legal problems that arise. For this reason, health practitioners are encouraged to improve the behavior of implementing medical records regularly and with quality. If not done then those who based on cross tabulation between sex and concern found that respondents who were female had more concern to complete the medical record 
compared with respondents who were male. Where this is due to the fact that female respondents are more patient in writing than men.

Based on the results of cross tabulation between age and care, it was found that respondents aged 25-45 years were more concerned to fill out a complete medical record where it was because at that age they still had a high enthusiasm to always do something and a high desire to do things perfectly

Based on the results of cross tabulation between years of work and care, it was found that respondents who worked for 6-10 years did not care to complete the complete medical record where it was caused because during the work period they still did not master how to fill a good and complete medical record.

Based on cross tabulation on marital status, it is found that respondents who are married are more concerned to fill out the complete medical record. Then in the educational history, diploma graduates are more concerned with writing a complete medical record which because they have high dedication and understand the importance of Medical Records ..

Discipline of health practitioners in completing medical information in accordance with the type of service that has been provided to patients is the key to the use of the above RM. However, there are still many doctors and nurses who are reluctant to fill RM properly due to time constraints or the assumption that RM is only important for hospital administration purposes (Dewi, 2009).

Based on the cross tabulation between sex and concern, it was found that respondents who were female had more concern to complete the medical record compared to respondents who were male. Where this is due to the fact that female respondents are more patient in writing than men.

Based on the results of cross tabulation between age and care, it was found that respondents aged 25-45 years were more concerned to fill out a complete medical record where it was because at that age they still had a high enthusiasm to always do something and a high desire to do things perfectly

Based on the results of cross tabulation between years of work and care, it was found that respondents who worked for 6-10 years did not care to complete the complete medical record where it was caused because during the work period they still did not master how to fill a good and complete medical record.

Based on cross tabulation on marital status, it is found that respondents who are married are more concerned to fill out the complete medical record. Then in the history of education, diploma paramedics graduates are more concerned in writing a complete medical record where it is due to better understanding of patient needs.

Concern is the sensitivity of attention which gives rise to an empathy attitude towards the distress / suffering of others, who not only feel sorry but there is a willingness to make the slightest movement as a form of expression. Based on the results of the study found that the majority of respondents care to write the contents of the medical record according to the activities he had to do to the patient. Where it is health care workers consider that the completeness of writing medical records is very necessary for the continuity of therapy. However, a small number of respondents did not care to write to the medical record where it was caused because the health workers thought filling out the medical record needed a long time so that the staff could waste time while working. in addition, health workers are less willing to correct the completeness of medical records that have been filled.

\section{Medical Record Writing Award By DPJP, Paramedics, Nutritionists, Pharmacists at the Regional General Hospital Dr. Sayidiman Magetan}

The results showed that the majority of respondents had a high appreciation of 136 respondents $(70.8 \%)$. Whereas 56 respondents $(29.2 \%)$ had low appreciation.

Recognition is part of the award given by the organization to its members for their work, achievements, dedication, and dedication to the organization (Robbins, 2012). If recognition is associated with Maslow's five-level theory of needs, recognition is part of the fourth level of need. This shows that recognition becomes dominant when three other needs have been met, namely physical needs, security needs, and social needs.

According to Salami's (2013) research, the completeness of charging RM is related to financial compensation which is the main tool to meet the first level needs, namely physical needs. This is also made worse when management's attention to the RM is still low. Recognition will be an interesting motivational factor if the employee is in a period of economic adequacy (Robbins, 2012). 
Based on the cross tabulation, it is found that respondents who are female are more likely to be rewarded when doing work starting from understanding and attention when filling out the complete medical record. Based on the results of cross tabulation between age and award, it was found that respondents aged 25-45 years wanted a higher appreciation in writing medical records.

The award is an effort to encourage employees to improve their work, the most effective award is an organizational award where if they are introduced the award refers to the total amount of money and non-monetary and benefits provided to employees by the employer in return for work performed in accordance needs and as part of an employment relationship. Based on the results of the study it was found that the majority of respondents have a high appreciation in which health workers say that if the medical record is filled in completely then the health worker will get appreciation from the head of the room and also the hospital supervisor, while for awards in the form of material and royalties are rarely given to health workers so that this causes some respondents to rate that the award given is low.

\section{Compliance with Medical Record Writing by DPJP, Paramedics, Nutritionists, Pharmacists at the Regional General Hospital Dr. Sayidiman Magetan}

The results showed that the majority of respondents did not comply to write medical records of 107 respondents (55.7\%). While 85 respondents (44.3\%) complied to write medical records.

Completeness in filling out medical record files by doctors can facilitate other health workers in providing actions or treatment to patients, and can be used as a source of data in the medical record section in managing data and reports that serve as useful information for the hospital management in determining the evaluation and health service development (Hatta, 2012).

According to the Ministry of Health (2008), medical records must be immediately made and completed in full after patients receive services provided that every act of consultation is conducted with the patient, no later than 24 hours must be written in the medical record sheet. In the question about reward and punishment, $100 \%$ of respondents answered that they did not receive reward and punishment because there was no reward and punishment system in completing medical records.

Based on Milgram's experimental theory (2011) that some factors that influence compliance are responsibility, where people who have a strong commitment or personality tend to be more obedient than those who have low commitment and also the support of colleagues from their peers to remind one another and when they see his friends obey so they will also obey.

Based on the cross-tabulation between sex and compliance, it was found that respondents who were female were more compliant to complete the medical record compared to respondents who were male. Based on the results of cross tabulation between age and compliance it was found that respondents aged 25-45 years were not compliant to complete the medical record completely.

Based on the results of cross tabulation between years of work and care it was found that respondents who worked for 6-10 years were not compliant to complete the medical record completely where it was caused because during the work period they still did not master how to fill in a good and complete medical record. Based on cross tabulation on marital status, it is found that respondents who are married are not compliant to complete the medical record completely. Then in the history of education, diploma paramedics graduates do not comply in writing a complete medical record.

Compliance is the level of officer behavior directed at instructions or instructions given in the form of any prescribed therapy, whether diet, exercise, medication or appointment with a doctor, which affects the health worker's compliance with filling in the Integrated Patient Development Record (CPPT) at the General Hospital. Based on the results of the study it was found that the majority of respondents were not compliant to write a complete medical record where it was caused by health workers lacking in mastering how to fill a good and effective medical record, because health workers were sometimes confused in understanding the contents of the written medical record. Disobedience of health workers can be bad for patients and for hospitals where for therapy to patients can not be integrated properly, then after that the claim will also be difficult because the data provided by health workers there is no continuity with the diagnosis of the patient. However, there are some respondents who comply to fill out medical records which is because health workers have mastered how to understand and fill out medical records. 
Effect of Motivation on Compliance with Writing Medical Records By DPJP, Paramedics, Nutritionists, Pharmacists in the Regional General Hospital Dr. Sayidiman Magetan

Based on the results of the Linear Regression analysis the motivation variable towards compliance shows that the p-value of $0.015<0.05$ then $\mathrm{H} 0$ is rejected, so it is concluded that there is a motivational effect on the compliance of writing medical records by health workers at the Dr Sayidiman Magetan Regional General Hospital.

Based on the Law of the Republic of Indonesia Number 44 of 2009 regarding Hospitals (RS), Hospitals are service institutions for the community with their own characteristics that are influenced by health science, technological advancements and socio-economic life of the community and must be able to improve higher quality services and affordable by the community in order to realize the perfect health degree. Quality of service is a very important thing to be able to maintain the existence of a hospital. One of the parameters to determine the quality of hospital medical services is the medical record service.

Medical records are part of the archive that describes all activities by an agency within a certain period. Hospitals must have a medical record as a standard of service in the health sector that is useful for improving quality in providing optimal services to patients. According to Permenkes 269 of 2008 Medical Records are files containing records and documents about patient identity, examinations, treatment, actions and other services that have been provided to patients. Personnel who are entitled to fill medical records include general practitioners, specialist doctors, dentists, and specialist dentists, visiting doctors who treat patients in hospitals, residencies who are carrying out practices, care paramedics and non-care paramedics (MOH RI, 2013).

The problem that often arises in filling out medical records is the incomplete filling process, the writing of a doctor who is less specific about the diagnosis. This situation has an impact on internal and external hospitals, because the results of data processing is the basis for making hospital internal reports and hospital external reports. This report is related to the preparation of various hospital plans, decision making by leaders, especially evaluating the services that have been given which are expected to improve the evaluation results (Gyana, 2012).

Completeness in filling out the medical record file by a doctor can facilitate other health workers in providing actions or treatment to patients, and can be used as a source of data in the medical record section in managing data and reports that serve as useful information for the hospital management in determining the evaluation and health service development (Hatta, 2012)

According to Notoatmodjo (2012) that one of the factors that influence touch is motivation, where by using the senses that a person does to a certain object can produce desires and skills (Hidayat, 2012). In line with the research conducted, that the motivation possessed by officers at hospital $X$ can affect compliance in filling out medical record files. Only need to be more thorough socialization to officers to further maximize the filling of the medical record file.

Based on the results of the cross tabulation, it is found that respondents who have high motivation are more obedient to complete medical records completely. However, there are some respondents who have high motivation but are not compliant to complete the medical record completely where it is caused because the respondent does not know how to fill in the medical record properly according to the rules so training is needed in order to improve compliance in filling out the medical record complete.

Obedience itself is the end result of strong desires arising from one's motivation. High motivation will increase one's obedience in doing something. In this case what is done by health workers is compliance in completing complete medical records. This was proven based on the results of cross tabulation where most of the respondents who were highly motivated also had adherence to complete medical records. where it proves that there is a significant influence of motivation on the compliance of writing medical records by health workers at the Regional General Hospital Dr. Sayidiman Magetan.

\section{Effect of Concern on Compliance with the Writing of Medical Records by Health Personnel in the Regional General Hospital Dr. Sayidiman Magetan}

Based on the results of the Linear Regression analysis, the variable concern for compliance shows that a p-value of $0.025<0.05$, then $\mathrm{H} 0$ is rejected, so it is concluded that there is an influence of concern for compliance with medical record writing by health professionals at the Dr Sayidiman Magetan Regional General Hospital. 
The main uses of the medical record are as evidence of the course of the patient's illness and treatment that has been given, a means of communication among health professionals who provide care to patients, a source of information for research and education, and as a source in collecting health statistical data. the usefulness of medical records can be reviewed from several aspects namely administrative aspects, medical aspects, legal aspects, financial aspects, research aspects, educational aspects and documentation aspects. A good medical record contains complete data and can be processed into information, making it possible to do an objective evaluation of the performance of health services and can be the basis of education, research and development (Salsa, 2013).

The main responsibility for the completeness of the medical record lies with the doctor who is responsible for treating the patient. Completeness of writing in the medical record file is an important thing. An incomplete medical record does not provide enough information for further treatment when the patient comes back to the health care facility (Hendra, 2014).

Non-compliance with medical records can be caused by many factors. According to Fitiah (2012) the factors that cause the diagnosis are not filled in the clinical summary sheet because doctors are not concerned with written activities, doctors are more concerned with providing services, the number of patients so that doctors try to provide services quickly, doctors are still waiting for the results of laboratory examinations to better ensure diagnosis more specifically, busy doctors, limited number of doctors, lack of cooperation between nurses and medical record officers, doctors are less concerned about medical records.

The results of this study are in line with research Rahayu (2013), said that the limited time, communication between specialist doctors and health workers, especially nurses and medical records officers resulted in opportunities to complete the medical record file is also limited.

Based on the results of the cross tabulation, it was found that the majority of respondents who had a high concern but were not compliant to fill out the medical record so the researchers assumed that it was related to knowledge that was still lacking related to how to fill out a good and correct medical record.

The emergence of compliance to complete medical records can also be related to feelings of care that arise from health workers for patients that patients must be monitored properly through integrated medical record records so that all health care workers who handle these patients can provide maximum service. High concern will increase the compliance of health workers in filling medical records where this is evidenced by the results of cross tabulation in which most respondents who have a high concern also have compliance in filling medical records so that it proves that there is a significant influence of concern for compliance with record writing medical services by health professionals at the Dr Sayidiman Magetan Regional General Hospital.

\section{The Effect of Appreciation on Compliance with Medical Record Writing by DPJP, Paramedics, Nutritionists, Pharmacists in the Regional General Hospital Dr. Sayidiman Magetan}

Based on the results of the Linear Regression analysis of the rewards variable for compliance shows that the p-value of $0.665>0.05$ then $\mathrm{H} 0$ is accepted so it is concluded that there is no effect of rewards on compliance with medical record writing by health professionals in the Dr Sayidiman Magetan Regional General Hospital.

Medical records generally consist of patient data records performed in health services. Medical records are very important for patient services because with complete data can provide information in making diagnostic decisions both treatment, treatment, medical treatment and others. Doctors are required to make medical records according to applicable rules. Health service facilities such as hospitals have the obligation to provide health services in accordance with the main target and have administrative obligations to create and maintain patient medical records (Budi, 2011).

Completeness in filling out the medical record file by a doctor will be able to facilitate other health workers in providing actions or treatment to patients, and can be used as a source of data in the medical record section in data management and reports that will be used as useful information for hospital management in determining evaluation and development of health services (Hatta, 2012).

The problem that often arises in filling out medical records is the incomplete filling process, the writing of a doctor who is less specific about the diagnosis. This situation will have an impact on internal and external hospitals, because the results of data processing becomes the basis for making hospital internal reports and hospital extrem reports. This report is related to the preparation of various 
hospital plans, decision making by leaders, especially evaluating the services that have been provided which are expected to improve the evaluation results (Giyana, 2012). Seeing the importance of completeness of data in medical records for doctors, of course related to the behavior of doctors themselves in completing patient data on medical records.

The incompleteness of the medical record document is one of the problems because the medical record is often the only data record that can provide detailed information about the actions taken on the patient. The medical record file aims to support the achievement of orderly administration in an effort to improve the quality of health services in hospitals, then in filling out the medical record must be filled in completely so as to produce accurate and continuous information (Budi, 2011).

The main responsibility for the completeness of the medical record lies with the doctor who is responsible for treating the patient. Completeness of writing in the medical record file is an important thing. An incomplete medical record does not provide enough information for further treatment when the patient comes back to the health care facility (Pamungkas, et al., 2010). One material that can be used as a medical evaluation is the patient's medical record, because the medical record is a very important document in the hospital that can be used as an evaluation of the quality of services provided to patients (Mogli, 2006).

Erfavira (2012) explains that the longer a doctor works in a hospital, the doctor will understand and understand more about the benefits of filling out medical records, so that the doctor will make a good and complete medical record. Doctors in Boyolali District Hospital with a longer service period will have more experience than doctors who are still new in filling out medical record files. The Boyolali District Hospital doctor with a long working period still has many technical tasks and requires time to adapt to the work environment.

A good performance in a service process can be influenced by various things, but the compliance is not influenced by the rewards given by the institution to its employees. The awarding is to give appreciation in the form of institutional pride to its employees so that in this study it was found that there was no significant effect of rewards on the compliance of writing medical records by health workers at the Dr Sayidiman Magetan Regional General Hospital. Where this is due to health workers who get high appreciation because the performance he did was very good and not just because of concentration only in filling medical records. In this case, in increasing the compliance of officers in filling out the medical records needed is changing the pattern by giving a punishment (punishment) if the officer can not reach the target. So it's not an award that will take precedence to increase compliance but what is needed is to impose work targets.

\section{CONCLUSION}

1. Most of the respondents have high motivation that is 144 respondents $(75 \%)$.

2. Most of the respondents care to write in the medical record that is 160 respondents $(83.3 \%)$.

3. Most of the respondents have a high appreciation of 136 respondents $(70.8 \%)$.

4. Most of the respondents did not comply doing medical record writing of 107 respondents $(55.7 \%)$.

5. There is a motivational effect on the compliance of writing medical records by health workers in the Dr Sayidiman Magetan Regional General Hospital.

6. There is an influence of concern for the compliance of writing medical records by health workers at the Regional General Hospital of Dr. Sayidiman Magetan.

7. There is no effect of appreciation on the compliance of writing medical records by health workers in the Regional General Hospital of Dr. Sayidiman Magetan.

\section{REFERENCES}

Anwar, W. A. et al. (2016) 'Measurement of Completeness of Medical Records in Family HeaMeasurement of Completeness of Medical Records in Family Health Centre in El Shorouk City.', The Egyptian Journal of Community Medicine Vol., 34(3), pp. 69-77.

Apriyantini, D. (2016) 'Analisis Hubungan Kelengkapan Pengisian Resume Medis Terhadap Kesesuaian Standar Tarif INA-CBG' s Instalasi Rawat Inap Teratai RSUP Fatmawati Jakarta', Jurnal ARSI, 2, pp. 194-203.

Aufa, B. Al et al. (2018) 'Analisis Faktor yang Berpengaruh Terhadap Ketidaktepatan Waktu Pengembalian Berkas Rekam Medis Rawat Inap di RS X Bogor', Jurnal Vokasi Indonesia., 6(2), 
pp. $41-46$.

Bambang Soenarko, E. S. M. (2015) 'PENINGKATAN NILAI KEPEDULIAN SOSIAL MELALUI MODIFIKASI MODEL PEMBELAJARAN KONSIDERASI PADA MAHASISWA TINGKAT I PROGRAM STUDI PGSD FKIP UNIVERSITAS NUSANTARA PGRI KEDIRI Bambang Soenarko, Endang Sri Mujiwati', 26, pp. 33-47.

Budiawan, I. N. et al. (2015) 'Hubungan Kompetensi , Motivasi dan Beban Kerja dengan Kinerja Perawat Pelaksana di Rumah Sakit Jiwa Provinsi Bali Association of Competence , Motivation and Nurse Workload with Nurse Performance at Mental Hospital in Bali Province Metode Penelitian ini ad', Public Health and Preventive Medicine Archive, 3, pp. 179-187.

Dr.dr.Sutoto, M. (2016) Standar Nasional Akreditasi Rumah Sakit Edisi 1.

Istirohah (2016) 'Analisis kepatuhan dokter dalam mengisi rekam medis di rumah sakit umum daerah kabupaten boyolali naskah publikasi'.

Nugraheni, R. (2015) 'Analisis Pelayanan Rekam Medis Di Rumah Sakit X Kediri Jawa Timur Analysis Services Medical Record in Bhayangkara Hospitals Kediri-East Java', Jurnal Wiyata, 2(2), pp. $169-175$.

Padjonga, I. N. H., Ngalle, D. G. and Takalar, H. (2013) 'Faktor yang berhubungan dengan kelengkapan rekam medis di rsud h. padjonga dg. ngalle takalar', jurnal AKK, 2(2), pp. 10-18.

Revitasari, A. (2016) ' 86 identifikasi ketidaklengkapan pengisian dokumen rekam medis rawat jalan berdasarkan teori motivasi ekspektansi', Jurnal Administrasi Kesehatan Indonesia Volume, 4, pp. 86-96.

Riyantika, D. (2018) 'Analisis Faktor-Faktor Penyebab Ketidaklengkapan Pengisian Lembar Resume Medis Pasien Rawat Inap', Strada Jurnal Ilmiah kesehatan, 7(1), pp. 69-73. Available at: http://jurnal.strada.ac.id/sjik.

Sandu Siyoto 1, F. A. P. 2 (2016) 'ANALISIS IMPLEMENTASI STANDAR PELAYANAN MINIMAL REKAM MEDIK DENGAN KEPUASAN PASIEN DI POLI KANDUNGAN RSIA PURI GALERI BERSALIN KOTA MALANG', jurnal care, 4(2), pp. 64-73.

Sekaran (2006) 'Operasionalisasi Variabel', pp. 64-100.

Simanjuntak, M. (2018) 'TINJAUAN KEPATUHAN DOKTER DALAM PENGISIAN SAKIT UMUM IMELDA PEKERJA INDONESIA ( RSU IPI ) MEDAN TAHUN 2018', JURNAL ILMIAH PEREKAM DAN INFORMASI KESEHATAN IMELDA, 3(2), pp. 518-523.

Sultan, U. and Abidin, Z. (2013) 'REWARDS AND MOTIVATION AMONG ADMINISTRATORS OF UNIVERSITI SULTAN ZAINAL ABIDIN ( UNISZA ): AN EMPIRICAL STUDY', internasional Journal o Business and Socuety, 14(2), pp. 265-286.

Susanto Edy, S. (2017) 'MANAGEMEN INFORMASI KESEHATAN IV ; ETIKA PROFESI DAN HUKUM KESEHATAN', BAHAN AJAR REKAM MEDIS DAN IMFORMASI KESEHATAN (RMIK), IV, pp. 1-178.

widyoko, P. E. S. Y. P. (2012) 'Teknik Penyusunan Instrumen Penelitian’, 15(September 2012), pp. 67-94.

Undang-Undang Republik Indonesia Nomor 44 Tahun 2009 tentang Rumah Sakit

Istirochah. 2016, Analisis Kepatuhan Dokter dalam Mengisi Berkas Rekam Medis di Rumah Sakit Umum Daerah Kabupaten Boyolali, Semarang. (Tesis)

Lapau, Buchari. 2013. Metode Penelitian Kesehatan Metode Ilmiah Penulisan Skripsi Tesis dan Disertasi, Edisi Revisi, Jakarta

Peraturan Mentri Kesesehatan rupublik Indonesia Nomor 129/MENKES/SK/II/2008 tentang Rekam Medis Peraturan Mentri Kesesehatan rupublik Indonesia Nomor 269/Menkes/Per/III/2008 tentang rekam medis

Puti Nazhifa Afdhal. 2014, Analisis Hubungan arakteristik Dokter Pengisi Rekam Medis Dengan Kelengkapan Rekam Medis Rawat Inap Bayi dan Anak di RSIA Budi Kemuliaan. Jakarta.

Rachma Y. (2010) Pengaruh Karakteristik Individu Dokter dan Masyarakat.;4(1): 17-27. Petugas Pengembalian Berkas Rekam Medis (Pos Perawatan) terhadap Mutu Berkas Rekam Medis di Rumah Sakit Haji Jakarta tahun 2011. [Skripsi]. Universitas Indonesia, Jakarta.

Ridho, Khasib Mabrur et al, 2012. Analisis Faktoor-faktor yang Mempengaruhi Kepatuhan Pengisian Rekam Medis di Rumah Sakit Gigi dan Mulut Pendidikan UMY, Yogyakarta, 2012.

Rina Yulida. 2016, Hubungan Karakteristik Dokter dengan Kelengkapan Catatan Laporan Operasi di RSU Queen Latifa Yogyakarta Tahun 2016, Yogyakarta.. Jurnal Permata Indonesia Halaman 57- 
66 Volume 7, Nomor 2, November 2016.

Sabarguna, Boy S. 2017, Sistem Informasi Manajemen Rumah Sakit: Edisi Revisi. Yogyakarta: Konsorsium Rumah Sakit Islam Jateng-DIY.

Sugiyanto, Zaenal. 2016, Analisis Perilaku Dokter Dalam Mengisi Kelengkapan Data Rekam Medis Lembar Resume Rawat Inap Di Rumah Sakit Ungaran. Megister Ilmu Kesehatan Masyarakat Konsentrasi Administrasi Rumah Sakit Universitas Diponegoro 